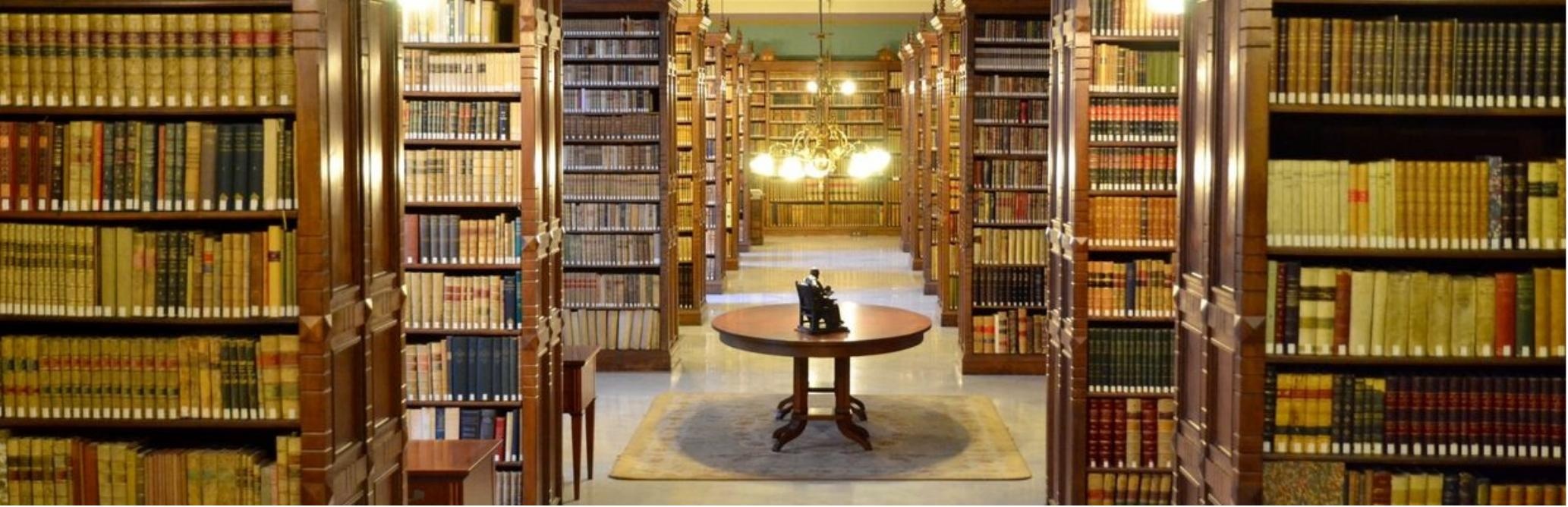

\title{
Editorial Volume 6, Issue 1
}

$\begin{aligned} \text { Authors: } & \text { María Fernanda Sandoval } \\ \text { Submitted: } & \text { 2. February } 2019 \\ \text { Published: } & \text { 3. February } 2019 \\ \text { Volume: } & 6 \\ \text { Issue: } & 1 \\ \text { Affiliation: } & \text { IASHA e.V., Freiburg, Germany } \\ \text { Languages: } & \text { English } \\ \text { Keywords: } & \text { Editorial, Josha Journal, } 2019 \\ \text { Categories: } & \text { News and Views } \\ \text { DOI: } & 10.17160 / \text { josha.6.1.534 }\end{aligned}$

Abstract:

The first month of 2019 has been very stimulating, check the " News \&Views" section on the left side of our homepage. We have been visiting and working with prestigious artists and musicians including video interviews and reports. In addition, we have published a number of important articles in the fields of Medicine, Architecture, among others, covering the spectrum of sciences, humanities, and arts. We are also constantly improving our Website for you. Now articles can be classified into more than one category. Furthermore, also videos may be added to your articles as a link. To watch press the button "Watch Video" at the bottom of the respective article. You may also select articles by sections such as Medicine etc. on the left side of the homepage. Furthermore, you may select articles by language and search words of your choice. Shortly, the statistics of each article will be available to our readers, covering the time since October 2019. Any further recommendations by our readers are welcome. Wishing you an enjoyable reading JOSHA experience! As always, all articles since the launching of JOSHA in 2014 are accessible free of charge. They have been viewed more than 440000 visitors and downloaded by more than 350000 readers as of January 2019.

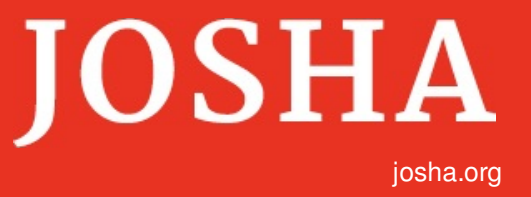

Journal of Science, Humanities and Arts

JOSHA is a service that helps scholars, researchers, and students discover, use, and build upon a wide range of content 


\section{JOSHA - Journal of Science Humanities and Arts Editorial Volume 5 Issue 10}

The first month of the current year has been very interesting concerning News \&Views. We were working together making contact and visits to prestigious to artist and musicians so they can be part of our upcoming events on the first and second half of 2019. We would like to invite you all to be part of this by watching our YouTube or Facebook page, where we are going to make public every JOSHA-event. In addition, we have been improving our Website for you, because is not only that all articles and submissions are available to belong to more than one category at the same time to provide an essayer way to find any article you need to read, but also videos can be added to your articles as a link. This will be able to watch by pressing the button "Watch video". In the same way, we are planning public statistics of the articles to provide our readers with better observation of the progress of their articles in terms of the number of downloads and views. In January we have received a total of 8 articles from Argentina, Kosovo, Germany, and Iran adding content to the categories of medicine, architecture, music, children's literature, and News \&Views.

\section{NEWS \& VIEWS}

Last year we have started with our first Demetrios Prize 2019. It was a pleasure for our journal to get so many submissions about many different topics participating for a publication in the journal. This time we are giving you again the opportunity to participate, to show to the world your researches and Ideas, and to win 500Euros. Follow the link of the title "DEMETRIOS PRIZE 2019" to see and get more information about this wonderful idea to promote and support the talent of young Students all around the world. The theses should be submitted by mail to admin@josha-archive.org until June 15, 2019.

Another upcoming and very interesting event will take place on 6 July 2019 in Freiburg with the "Dai Kimoto \& his Swing Kids"! Since 2005 Dai Kimoto and his Swing Kids have been playing themselves into the hearts of the people. The Swing Kids are jazz and a big band who play music with joy at the highest level! The 13-piece band is currently between 9 and 16 years old. When they play, you forget their age. In the context of this concert our team will celebrate and present the winners of the bevor mentioned DEMETRIOS PRIZE 2019. For more

(C2015 The Authors. Published by the International Academy of Sciences, Humanities, and Arts under the terms of the Creative Commons Attribution License http://creativecommons.org/licenses/by/4.0/, which permits unrestricted use, provided the original author and source are credited. 
information about this event sponsored by the International Academy of Sciences, Humanities, and Arts (IASHA e. V.), please contact Zazie-Charlotte Pfeiffer (zazie-charlotte.pfeiffer@josha-archive.org) and Eva Senn (eva.senn@bluewin.ch) or visit the Website of the Academy (http://iasha.org/).

\section{MUSIC, VISUAL ARTS, ARCHITECTURE AND DESIGN}

Starting with the musical area, Leander Hotaki, from Germany, presents his third column in German on an extremely interesting subject in the field of music. "Klassik-Doping - Classic doping" is about the types of doping that musicians use to keep their technique and musicality to the maximum. More of his column are up to come. From Kosovo we have brought you three paper in the field of architecture. The first of them entitle "Emergency Reconstruction of Primary Schools in post-conflict context: the case of Kosovo" was presented by Brendha Meka together with Vlora Navakasi, and Flaka Xerxa and the purpose of this study is to analyze the process of emergency design and construction of primary schools in the post-war period in Kosovo, from 1999 and afterward, also to investigate the impact of the used standards on the reforming of the educational system. The second article of this category was entitled "Humongous Traffic Rhythm: Urbane Fulmination for Parking Spaces in Prishtina" and presented by Bujar Bajçinovci, Vlora Aliu, and Rinë Dinarama. The study presented in this paper investigated the Prishtina City, focusing on urban planning issues, traffic issues, and urban data. The research methods consist of empirical observation, with an accent to the urban traffic structure. And the third article of this category shows us the important of make some changes to provide a better life for the future of Prishtina, concerning the urban stress and the spatial organization of the city. "Anxiety and Urban Stress for Parking Spots" says that the lack of a sustainable urban mobility plan for the city of Pristina and its linkage to spatial plans in the future will bring serious problems for the city, which will have a negative impact on the quality of life. You will find more about this and other topics by following the link of the titles.

$\mathrm{n}$ this category, we bring you an article from Buenos Aires, Argentina, presented by Dr. Virginia Perez. This paper shows us a research report on a topic of great interest in the area of medicine. "First-in-Human Research" is an article about the First research in humans which involves a wide variety of studies where the common factor is to test a new intervention, that is, never before tested in humans. In addition, it is a topic of interest for research.

(C2015 The Authors. Published by the International Academy of Sciences, Humanities, and Arts under the terms of the Creative Commons Attribution License http://creativecommons.org/licenses/by/4.0/, which permits unrestricted use, provided the original author and source are credited. 


\section{DEMETRIOS CHILDRENS BOOKS}

The beautiful children's book "The wise Gardener and the kind tree - in Farsi and German" from the author Neda Moshirian, from Iran. The story reminds children of ways to achieve goals and techniques for success in the form of fiction. Moreover, this is the second publication of the book, but this time it is written in Persian and German. The wonderful illustrations were handmade by Shirin Korehi achieving the perfect mix of colors that will capture the attention of the readers. We would like to remind our readers that you are able to get a print copy of any children's book you like by pressing on the button "order book".

We are happy to carry on a successful way with all your support and hope to have a wonderful 2019 overflowing with endless interesting articles from all over the world. The Editorial Board and everybody in JOSHA would like to thank our readers and authors for supporting this project. We also like to remind you to make comments on the articles as well as we wish all our readers a joyful reading experience.

Table of content: http://josha-journal.org/en/issues

Maria Fernanda Sandoval on behalf of the JOSHA Team 